\title{
The Role of SALGA in Training Municipal Councillors for Development: Using the "Knowledgeable" Experts
}

\author{
Mokoko Sebola \\ Department of Public Administration, \\ University of Limpopo, South Africa
}

\author{
Doi:10.5901/mjss.2014.v5n14p633
}

\begin{abstract}
The change in municipal administration of South Africa acknowledged the challenge of skills development in the administration of local governments. This led to the establishment of many legislative frameworks of providing good governance to South African local governments. It is a hard fact and reality that the implementation of such legislative frameworks plus their complexities in practice requires a professional administrative system and political system that is conscious and aware of the understanding of the complex local government environment systems. While the local government is considered a significant sphere to carry out the government's mandate of service delivery, it is significant that the sphere should have more skilled and expert administrators and politicians in order to deliver services to local communities effectively and efficiently. Training was seen to be provided through the initiatives of SALGA (South African Local Government Association) which carries a mandate to see the skills and capacity development of municipalities in the country. The effectiveness of financial resources spent on the training of municipal councillors was often queried, depending on the level of the stakeholders involved as beneficiaries of training programmes and the impact of the training provided by the "experts" contracted as service providers. This article will therefore argue that the one size fits all approach used to empower municipal councillors through training and the use of the business minded "knowledgeable experts" produced by the main stream Public Administration curriculum by South African universities which often neglect critical local government content may not be beneficial to municipalities and their councillors, and as such may lead to government financial resources not being effectively utilised. This article therefore questions and challenges the relevancy of the general mainstream Public Administration curriculum as a solution to address local government capacity skills problem. The article will therefore analyse the status of local government in South Africa, capacity building through training programmes as a means aiming at empowering municipal councillors, their effectiveness and impact, challenges facing local government education (curricula) and suggesting a policy change and workable solution to improve the status quo.
\end{abstract}

\section{Introduction}

The current political and management system of the South African municipalities emanate from a complete transformational structure of the pre-1994 municipal system. The transformation has taken its toll on a political, cultural, economic and physical level. That transformation came to be characterised by a change from a discriminative to a participative approach, gender discrimination to equality, apartheid policies to democratic policies, from the perception of local governments as administrative arms of government to public service delivery sites for government, from maintenance of old municipalities to the creation and establishment of the new municipalities in the rural areas and from the utilisation of the "experienced" to the utilisation of the "inexperienced" in the new municipalities. That indeed became a challenging and mammoth task to be carried out by municipalities of the new dispensation. The South African government often uses a one size fits all approach to deal with rural municipalities' capacity development as if they are equal to their metropolitan counterparts. That could be a misleading administrative error. A major assumption made in this article is that the mainstream Public Administration of South African universities do not absolutely cover the critical content of local government education in their instructional offerings and therefore experts produced by such content may not necessarily be able to provide effective local government training. This article, however, focuses on the aspects of training councillors for development in South African municipalities as an objective that cannot be achievable in totality because of a lack of appropriate curricula in institutions that address local government education. The research questions addressed in this article are as follows:

- What is the status of local government?

- Did the implementation of legislative frameworks plus their complexities create an understanding of the 
complex government environment systems?

- Was the one size fit all approach to training and the use of business minded "knowledgeable experts" successful?

- How relevant is the general mainstream Public Administration curriculum as a solution to address local government capacity skills problem?

In addressing this questions; this article will therefore keep its relevance by providing background of local governments in South Africa, the notion of capacity building and service delivery in South Africa and the role and challenges facing SALGA in capacitating councillors for valuable performance in their political task and provision of leadership; and whether SALGA have the potential to improve training for councillors in regard to existing challenges

\section{Local Government in South Africa}

Local government is said to be a system consisting of the community management and the administration (Cloete 1995). Although the sphere by virtue of its level looks insignificant, it is the most significant sphere that deals with pragmatic political, social and economic affairs of a country. It is at this level that practical policy implementation takes place. Local governments are regarded as context of the everyday lives and the only level of government that has a constant impact on the physical and human social environment within which humans live (Box 1998:41). Powers, Brown and Arnold (1974:7) also indicated that in reflecting the society that has created them, local governments are perceived as changing institutions filled with incredible stress and tensions as new demands are placed upon them for attention. As Wamsley and Wolf (1996:146) argue further on this they indicated that contexts are characterised by structures, patterns or constellations of social forces developed out of governance and administrative history. Modern practical realities in South African local governments create the image of the local government as an inferior sphere to its counterparts, the provincial and the national spheres of government. Even if local politics are regarded inferior by those at national level politics, this is the sphere that requires careful consideration both in the context of political and management setting. To a particular extent in South Africa local politicians and public officials with good skills are absorbed into either provincial or national politics or administration on the pretext that their skills are underutilized at local government level. Such an approach is incorrect in the sense that it implies that local governments does not need good skills and expertise as the provincial and the national government may require, especially in the rural areas of the country. Sustainable metropolitan municipalities in the country are able to recruit and absorb good skills and expertise. Such practice and attitudes may continue to deny the truth about the existence of the new local government system which emanated from the need to eradicate injustices of the past and to introduce a complete transformation and changed perceptions about the role of rural municipalities in development and service delivery.

Local governments in South Africa carry a legislated mandate which is to serve the interest of the public through equitable service provision. Gildenhuys (1997:2) indicated that the existence of a municipal office in a demarcated area is not simply to keep councillors and public officials on government's payroll, but rather to provide service to the public. Both councillors and officials should be individuals that are ready to serve and account to the public for their activities in the office. On the same note, it is significant to consider the constitutional mandate of the local governments in South Africa which are to:

- Provide democratic and accountable governments for local communities;

- Ensure the provision of services to the communities in a sustainable manner;

- Promote social and economic development;

- Promote a safe and healthy environment and

- Encourage the involvement of communities and community organisations in matters of local government.

Organisational objectives are set by organisations for the purpose that they must be met. Meeting the set objectives for local governments in this context is dependent on the knowledge base of both councillors and officials about their constitutional mandate. The training and knowledge received by an organisation's employees often to a certain extent contribute in making set organisational objectives achievable.

The Constitution of South Africa, 1996, assigned new roles to modern municipalities which most of them are common to the previous city and metropolitan municipalities while some duties are new to new occupants of municipalities' leadership in rural areas. They were assigned new powers and functions. The Constitution addresses the issue of municipal powers and functions in two categories (Bekink, 2006:215). It provides for powers and functions of municipalities while it also indirectly incorporates and mandates certain issues that are also important to municipal powers and functions. The constitutional powers and functions are executed within the context of administrative activities 
which Public Administration scholars, despite the on-going debates within academic circles, categorised it into four groups, namely generic administrative and delivery, auxiliary, instrumental, and functional, also referred to as functions (Cloete, 2004:85). Although the generic approach has been criticised in the wake of repositioning the state of Public Administration in South Africa, the approach still remains a workable base for the practice of public administration, especially in local government. In practice the groups of functions are usually carried out simultaneously and are integrated to such an extent that it is often hardly possible to see where one ends and the other begins (Cloete, 2004:85).

\section{Capacity Building and Service Delivery}

Capacity building in general terms refers to the ability to perform appropriate tasks effectively, efficiently and sustainably (Grindle \& Hildebrand, 1995; Cloete, 2002). In the context of the new and adopted service delivery approach by the state it refers to a total (structural, functional and cultural) transformation of government in order to mobilise all the available resources to achieve policy objectives (Savitch, 1998; Cloete 2002). Thus far the realities in local government administration in South Africa dictate that a great deal still needs to be done to improve the level of capacity building for purpose of service delivery to be carried out appropriately. As Cloete (2002:287) indicated, the local governments in South Africa face various challenges which include among others appointment of inexperienced and uncommitted political office bearers, outdated local governments structures and lack of revenue base. In the same vein Motshekga (1994) has echoed that rural municipalities face various problems which include mostly gender inequality and poor revenue collection. As argued in various pieces of literature on a similar subject, not all of the identified problems within the local governments require training as a solution. A change of attitude by municipal officials, politicians and the ruling government may bring about a good solution to municipal capacity skills development problems. That would help to empower local governments to achieve service delivery mandates. In the current political setups and practices of South African politics it is argued that local governments are not viewed as significant in political administrative terms. Local politicians are using the sphere as a stepping stone to provincial and national level politics. It still continues to be viewed as a primitive sphere which only serves to create and nurture talent required at provincial and national level politics. Ultimately politics at local government level remains permanently premature. That also creates a situation where good skills at local level government level are nurtured and developed for transfer to either a provincial or national level. Capacity building at local government level remains a challenge as the function of the sphere continues to be undermined by those at upper political level. This is despite the fact that the local government sphere remains the most significant sphere where actual service delivery is taking place.

\section{SALGA and Its Role in Capacity Building}

The White Paper on Local Government (1998) indicated that for developmental local government to be possible with regard to service delivery, the municipalities have to develop at least three sets of new capacities such as strategic capacity, integrating capacity and community orientation. It is therefore believed that if these three capacities can be taken care of municipalities will be able to sustain themselves and their service delivery objectives. The White Paper on Local Government (1998:12) acknowledged that the current training system has been labelled inefficient and unresponsive to the training needs of local government. The role of SALGA in capacity building therefore becomes imperative and it is also believed that it will address the inefficiency and the irrelevance of the existing training system to the benefit of municipal officials.

\subsection{SALGA and capacity building}

The objectives of SALGA as outlined in its constitution are as follows:

- Represent, promote and protect the interest of local government

- Transform local government to fulfil its developmental role

- Enhance the role and status of its members as provincial representatives and consultative bodies of local government

- Enhance the role and status of municipalities

- Be recognised by national and provincial governments to be representative and consultative body in respect of all matters concerning local government and to make representations to both provincial and national governments in respect of any matter concerning local government 
- Ensure the full participation of women in organised local government

- Be the National Employers Association representing all municipal members and, by agreement, associate members

- Regulate the relationship between its members and their employees within the meaning of section 213 of the Labour Relations Act 66 of 1995, as amended

- Provide legal assistance to its members, in its discretion

- Encourage the settlement of disputes among its members and between them and their employees or trade unions through co-operative governance or labour law principles

- Affiliate with and participate in the affairs of any international organisation, that will serve the interests of its members

- Do such lawful things as may be appear to be in the interest of the organisation and its members which are not inconsistent with the objects or any matter specifically provided for in this constitution; and

- Borrow, invest, lend subscribe or donate money for the furtherance of the objectives of the organisation.

From the aforementioned objectives it becomes clear that SALGA carries a major mandate of ensuring that municipalities carry out their developmental function with the highest level of efficiency and effectiveness. As clearly indicated in the White Paper on Local Government (1998:13), the training of local government is not the responsibility of the Local Government Sector Education and Training Authority, but the responsibility of SALGA. But the question of the capacity of SALGA in fulfilling this mandate is a serious concern raised in this article. Bearing in mind the complexities regarding the concept of capacity, the use of institutions for such training and the challenging realities of the typical councillors in South African municipal systems, it becomes difficult to determine and confirm SALGA's capacity in dealing with training for development in South African municipalities.

\subsection{Contextualising capacity building}

Capacity building in the context of this article refers to the ability to perform appropriate tasks effectively as expected by the nature of one's position in his or her municipality. The concept of capacity has, however, presented itself in the manner which is very ambiguous in South African context and poses various semantic challenges. The study by the Department of Corporative Government and Traditional Affairs in South Africa (formerly known as Department of Provincial and Local Government) revealed that capacity has various meanings to various municipalities in the country. According to the National Capacity Framework for Local Government of 2008-2011 (Department of Provincial and Local Government, 2008:26), it has been noted that during the implementation of Project Consolidate, it became apparent that stakeholders used the term capacity in a variety of ways. It has been noted that for some people it means the volume of posts filled, or more definitely, the number of posts filled by appropriately qualified skilled and orientated people in the institution or sector. To others it simply means technical "know-how" which may be gained through formal skills training or from experience. Others use the term to refer to change management capability, that is capacity to transform and improve a system or institution or strategic management capabilities such as the capacity to develop a strategic overview, prioritise interventions, and act in areas of maximum leverage. Some people view it as an attitude, such as a commitment to social and economic emancipation, and a willingness to champion interventions in line with commitment; while others see it as a way of working, such as the stamina and tenacity to make steady progress. Others just view it as a sense of public integrity. Capacity therefore poses serious challenges and misconception. This article will however align its understanding of capacity more with the technical "know-how" than any other meaning that can be attached to the concept. Thus far the lack of technical know-how in both the municipality and the public service has compromised the effective delivery of service to the South African citizenship owed to them by their municipalities. In South Africa service provision is a right and not a privilege.

\section{Challenging Realities in South African Local Governments}

Previously Local government training used to be coordinated by two functioning boards, namely Local Government Education and Training Board and the Training Board for Local Government Bodies. Both bodies were levying municipalities and therefore there was duplication of activities and objectives by these two bodies. Ultimately, Local Government Education and Training Board replaced the two bodies in which it has to serve as a coordinating body for local government training, but with its activities limited to managing a local government training fund, allocating such funds to the provincial training structures, setting national training priorities, establishing standards, accrediting service 
providers and providing training certification. That sounds like a workable solution, in which instance the Local Government Education and Training Board facilitates training processes while SALGA takes the full responsibility of training, but pragmatic realities in the South African local governments environment present a different challenging perspective, which makes the impact of training to be minimally recognised as a solution to councillor development for service delivery in South African local governments. Some of the challenging realities that need serious engagement include institutions that provide local government training, knowledge base for local government in South Africa, knowledge resources in local government education and the nature of the politics of South African local government councillors.

\subsection{Institutions of Local Government training}

The White Paper on Local Government (1998:13) indicated that a variety of contractors in South Africa qualifies to provide training to local government councillors and officials. That is on condition that such institutions' learning materials respond to the needs defined by Sector Education and Training Authority (SETA) and Provincial Training Structures. Such institutions include Non-Governmental Organisations, Universities and Universities of Technologies, Private Sector Companies and Centres, Provincial Training Centres, Commercial training and Development consultants, and Professional bodies. A holistic approach to solve training problems in this manner adopted by the country raises questions of doubts of standards and quality of education to be provided. This approach exposes the local governments to vulnerability to mediocre training provision. The institutions named as training providers have different approaches of culture and standards of training that they provide. The provision of municipal councillor development training deemed possible by the White Paper on Local Government opens a leeway for different qualities of municipal councillor development training programmes. Universities and the Non-Governmental Organisations may not provide same quality of municipal development training programme as anticipated by SALGA. They may use training facilitators of an unequal knowledge base which will also impact negatively on the training provided, especially if the approach to the training of councillors is viewed in business terms than in developmental terms.

\subsection{Knowledge base for Local Government in South Africa}

Kanyane (2008:519) listed some selected South African higher educational institutions that offer Public Administration and Management as a discipline. Those institutions include University of Stellenbosch (US), University of Western Cape (UWC), University of KwaZulu-Natal (UKZN), North West University (NWU), University of Cape Town (UCT), University of Pretoria (UP), University of Limpopo (UL), University of the Witwatersrand(WITS), Nelson Mandela Metropolitan University (NMMU), University of Free State (UFS), Tshwane University of Technology(TUT), University of Fort Hare (UFH) and University of Venda (UNIVEN). University of Southern Africa (UNISA) and Durban University of Technology (DUT) also offers Public Administration and Management respectively. It is believed that institutions that offer Public Administration and Management as a discipline are automatically capable of providing local government knowledge. That cannot be an absolute pronouncement on this matter. Kanyane (2008:517) further indicated that of these listed universities only three such as University of Witwatersrand, University of Fort Hare and University of Limpopo offer accredited degrees and certificates in local government education. It can be argued that the knowledge base in Local government of South Africa is still lacking behind in terms of the required educational knowledge required for skills development in that field. South African Universities offering degrees in local government education may not be trusted with full knowledge content about the local government. At the University of Limpopo, B. (Admin) Local Government which is the only programme accredited to offer Local Government courses in the province, only offers such modules from first year to second year level (University of Limpopo Institutional Research and Planning, 2011: 96). Other universities offering such instructional modules although accredited are within the centre of businesses section in their universities. In reality there is no an absolute Public Administration curriculum in South African universities that addresses local government education in totality. Thus far South African Universities offer little knowledge of local government education in the discipline of Political Science, Development Management and Public Administration. In general most Public Administration curriculum in South African universities has no content that deals with local government issues. Instead a little content on local government issues is provided in structured masters courses offered in the discipline of Public Administration such as Master of Public Administration (MPA). In some institutions the module on local government in such programmes is an elective and post-graduates in the programme often do not even elect the module. It is therefore arguable that the knowledge provided for by South African universities on local government education is not sufficient to build an acceptable knowledge base for the beneficiary of such training programmes in local governments. 
The needs survey presented by SALGA in 1997 showed that the training needs of councillors required in terms of priorities are Integrated Development Planning (IDP), Budgeting and Financing, Strategic planning, service delivery, human resource development and change management (Kanyane, 2008:514). Local Economic Development (LED) training also became a critical aspect of local government requiring urgent attention. While other modules such as strategic planning, human resource and change management may well be articulated within the Public Administration and Management discipline, service delivery, IDP and LED modules within the local government education are new and require specialised training of providers before they can engage in their instructional offering. Such modules were never addressed properly or catered for within the general mainstream of Public Administration curricula. However, Kuye (2007) noted that Universities have a significant role to play in the training for development in municipalities. Kanyane (2008) noted that in their pro-activeness and engagement of institutions of higher learning, municipalities should ensure that they use reputable schools and departments of Public Administration to design specialised programmes that addresses their limitations. This means that it is recognisable by Public Administration scholars that not all Public Administration curricula may absolutely address local government education, except in relative academic assumption that the sphere cannot be studied separately from the Provincial and the national sphere. That is despite the fact that the critics of my assumption in this article agree that local governments in the country are managed through separate legislative frameworks designed for the provincial and the national government. The design of the curricula of Local government should therefore be done by people with expert knowledge in local government administration as an academic discipline.

As informed by the current management crisis in local government, it can only be argued that the discipline of Public Administration has left an enormous knowledge vacuum in local government education; and therefore exposes local governments to administrative scandals in which the administrators in local governments only managed to learn legislative frameworks relevant to the provincial and national government and missed an opportunity to learn relevant local government legislative frameworks such as Municipals Systems Act and Municipal Structures Act. Thornhill (2010) in his article, The Domain of Public Administration questioned the relevance of Public Administration curricula and at the same time recommends that it must be aligned to the current public administration activities which will include alignment to the role of the state, private sector, NGO's and municipal legislation. To this extent the expertise of South African academics in local government education remains partially acceptable considering that no absolute specialised curriculum in the discipline exists in institutions of higher learning in the country. Mostly because not all Public Administration curricula address the content of the discipline of local government. Even those within the Public Administration discipline that includes Local Government content in their curricula, remain too limited in scope and little attention is paid to its recognisable existence.

\subsection{Knowledge resources in Local Government education}

A vast volume of literature exists in the discipline of Public Administration in South Africa. A great deal has been written in the discipline and most of them address generic Public Administration curricula content such as constitutionalism, public policies, ethics, public personnel management and public finances. There are at least three scientific journals that exist for the maintenance of the credibility and the status of the discipline of Public Administration in the country. Those include Journal of Public Administration (JOPA), Politeia and Administratio Publica. However the authorship in the journals is not limited in terms of scope of authoring articles, only few issues published in these three journals annually addresses critical local government content. Publications are dominated by articles addressing issues of national importance. The Journal for local government (supposedly a journal of the Institute of Local Government and Management (ILGM) hosted at the Tshwane University of Technology) which was the only journal meant to address local government issues in the country failed to secure accreditation with the Department of Education mostly because articles published prior to application for accreditation in it were mostly focusing on generic public administration matters instead of critical local government issues. That shows a significant knowledge gap about local government education in the country. There are significantly very few books published in the discipline of local government which mostly repeated published editions by Crythorne and Gildenhuys. Even in that regard most books published in local government mainly deal with local government finances rather than with LED, IDP, Local government politics and the administration of local government. This implies that despite the significance of local government as a sphere that is closer to the people; the sphere significance continues to be marginalised in terms of significance and consideration. Based on insufficient knowledge resources in the discipline of local government, it may be problematic to have genuine trainers provide quality training that will impact positively on the beneficiaries of the system. 


\section{The Politics of South African Municipal Councillorship and Training for Development}

The nature of the politics of local government in South Africa follows the approach of populism than ability or populism combined with ability. The system of politics in local government promotes individuals politically while undermining their capacity to perform their political responsibility. The previously used system of part time councillors of whom the majority had a good educational level created tensions of local politician in various South African local government politics. The government succeeded in removing such councillors on issues that they are double dipping on government employment [this doesn't make sense]. The government's decision on this matter puts SALGA's capacity on this task at risk. It is unachievable and difficult for SALGA to attain the objective of capacity building for councillors while the majority of councillors may be dominated by individuals with a questionable educational level.

Rankhumishe and Mello (2011:789) indicated that on-job training is an important intervention that makes employees of a particular organisation productive. That is also dependent on the level of educational knowledge that employees possess at the time of such training. Mafunisa and Tsanwani (2011:82) articulate that apart from formal education, employees still require skills training in order to fit well into the job market. The realities in South African politics are that SALGA may find it difficult to have benefitted councillors with their training programmes because of the level of education of councillors in most South African municipalities. Some of them are at the level at which training cannot be a beneficial means to acquire knowledge. Training is often conducted in English, a language that the intended beneficiaries do not know. Things are likely to get worse when part-time councillors are phased out. Most of them were literate and made significant contributions towards municipal development. Such officials have indicated to be knowledgeable in most training conducted for councillors, other than the populists councillors with lower educational levels to understand the teaching provided.

\section{The Best Choice, Does SALGA Have One?}

SALGA carries the mandate to ensure that local governments in South Africa achieve their developmental mandate, mostly through empowerment and capacity building. It should be realised that local governments' delivery of service represents the success or the failure of both the provincial and national government. The said two spheres achieve both their political and developmental goals through local government. A lack of building a strong, sound and sustainable local government threatens the national government's ability to achieve its mandate. Thornhill (2010:72) mentioned that the perception about the quality of government and government institutions is mostly measured by the quality and administration of the local government. The neglecting of local government education in various South African institution of higher learning puts SALGA's mandate of empowering councillors through training at risk. SALGA as an institution established by the law to represent the interests of local governments should ensure that its clients get thorough and effective training. However, there are courses compiled and accredited through LGSETA. SALGA should guard against the abuse of such instructional offerings for business by academic and private sector institutions. As Labuschagne (2010:96) put it, in a country such as South Africa where patronage supersedes merit, it could be difficult to consider the valuable outcomes of any project. But Binza (2010:251) mentioned that one of the greatest challenges facing the role of local government with regard to local economic development is the lack of knowledge about local government issues. This still supports the view raised in this article that local government education has not been properly promoted in South African institutions of higher learning. Academic authority on this subject is often difficult to determine and confirm among South African academics. SALGA should therefore ensure that it encourages institutions of higher learning to consider the curricularisation of local government degree programmes in universities to address the challenges of critical local government issues fully. That will help to improve the knowledge base and areas of research in local government.

\section{Conclusion}

This article argued that local government education does not receive proper attention by academic institutions in South Africa. That is believed to have a negative impact on the training provided by such institutions to municipal councillors, through SALGA's initiatives. The article argues that there are various challenges facing SALGA in empowering and capacitating municipal councillors through its training programmes. Such challenges can only be dealt with appropriately if local government education and training can be strengthened through credible academic institutions and a change in approach of the election of councillors in the sense that they move from the populist to the ability and knowledge driven approach. There must be a particular educational level to be reached by an individual to compete in municipal councillor elections. That will avoid a situation where councillors without an educational background benefit less or little from the 
training which is provided in a language foreign to them.

\section{References}

Bekink, B. 2006. Principles of South African Local Government Law. Durban: LexisNexisButterworths

Binza, M.S. 2010. Developmental Local Government in the 21 ${ }^{\text {st }}$ century. Implementing Local Economic Development as a new mandate. Administratio Publica. Vol 18(4): 241-225

Cloete, F. 1995. Local Government Transformation in South Africa. Pretoria: J.L Van Schaik

Cloete, J.J.N 2004: Introduction to Public Administration. Pretoria: J.L Van Schaick.

Cloete, F. 2002.Capacity Building for Sustainable Local Governance in South Africa. In S, Pannel, E, Pieterse, M, Swilling and D, Woolridge (Eds). Democratising Local Government in the South African Experience. Cape Town: UCT press.

Department of Provincial and Local Government. 1998. Pretoria: Government Printer.

Gildenhuys,J.S.H 1997. Introduction to Local Government Finance. Pretoria: J.L Van Schaick.

Grindle, M.S. and Hilderbrand, M.E. 1995.Building Sustainable Capacity in the Public sector: What can be done? Public Administration and Development. Vol. 15(5):441-463.

Kanyane, M.H. 2008. The Role of Educational Institutions in Professionalising IDP Training. Journal of Public Administration. Vol 43(3.2): $512-519$

Kuye, J.O. 2007. A Decade of review of Higher Education in South Africa. African journal of Public Affairs. Vol. 1(1): 2-6

Labuschagne, P. 2010. Local Government and Service Delivery in South Africa. An investigation into the defence of necessity. Administratio Publica. Vol.18 (4): 93-105

Mafunisa, M.T. and tsanwani, A.P. 2011. Addressing scarce and critical skills in Limpopo Local Government: The LGSETA option. Journal of Public Administration. Vol. 46(1.1): 881- 811

Motshekga, M. 1994. Views on Local Government. In Nthai, S (ed).Local Government. Focus on rural Local Government. Johannesburg: The Booksworks.

Rankhumishe, E.M. 2011. The Implications of Training Measures to the Development action appointees: Insights from Mpumalanga Public hospitals. Journal of Public Administration. Vol. 46(1.1):785- 797

Thornhill, C. 2010. Local Government Democracy in Africa. Fact or Fiction? Administratio Publica. Vol 18(4): 71-90

White Paper on Local Government. 1998. Pretoria: Government Printer

University of Limpopo. 2010. Institutional Research and Planning. University Programme and Qualification Mix. Sovenga: Turfloop Press 